\title{
HOPES FOR THE COUNTRYSIDE'S FUTURE. AN ANALYSIS OF TWO ENDOGENOUS DEVELOPMENT EXPERIENCES IN SOUTH-EASTERN GALICIA
}

\author{
Valerià PAÜL \\ University of Santiago de Compostela, Spain
}

\begin{abstract}
The Galician countryside is commonly interpreted as being dominated by a deep socio-economic depression that even the reception of generous European Union rural and regional development funds over the last few decades has not been able to overcome. The aim of this paper is to refine this negative understanding at regional scale by examining specific case-studies at local level through a qualitative study of two self-proclaimed "rural development centres" located in south-eastern Galicia (the province of Ourense). The research is carried out within a theoretical framework on development, based mainly on the core notion of endogenous development. After outlining the regional setting, the selected experiences in the hamlets of Lodoselo (municipality of Sarreaus, district of A Limia) and Arzádegos (municipality of Vilardevós, district of Val de Monterrei) are analysed. The paper concludes by discussing to what extent both initiatives follow endogenous development conception and contribute towards real rural development, thus avoiding the bleak regional picture. The relevance of qualitative readings is stressed in this respect.
\end{abstract}

Key Words: Sustainable / rural / regional / endogenous / neo-endogenous development, demographic ageing and depopulation, agriculture and tourism in rural areas, qualitative research methodology, province of Ourense (Galicia, Spain, European Union).

\section{Introduction}

It is plainly clear that there is a widespread perception that rural Galicia is presently undergoing a profound crisis. In the Galician countryside, districts in the province of Ourense ${ }^{1)}$ are considered to be in a particularly delicate state. Thus, in a geographical analysis, Lois (2004: 123-124) states that "in many parts of the province of Ourense" we observe "an invading sense of slowdown", loss of population "at an alarming rate", "a shockingly ageing population" and "communities overtaken by a sense of resignation and despair". In the same vein, a sociological study argues that 8 out of the 12 districts in the province of Ourense (along with 4 in the province of Lugo) show the poorest situation in Galicia through "excessive and disturbing demographic decline" (Trabada 2007: 32). According to this author, these districts are characterised through "a low-spirited atmosphere of socio-cultural and economic decline, one which lacks the trappings and dynamic relationships and does not make young people and young families feel at ease" (Trabada 2007: 41). In short, the overall Galician countryside

1) Galicia, with 2.772 .928 inhabitants (2011 census data) on $29.574 \mathrm{~km}^{2}$, is administratively divided into four provinces, which approximately covers a quadrant each (Fig. 1). Ourense is located in the southeastern quadrant, with 333.257 inhabitants (2011) and $7.273 \mathrm{~km}^{2}$. While the density of the Galician population is 94 inhabitants $/ \mathrm{km}^{2}$, the province of Ourense registers less than half of the said indicator. The provinces are divided into districts (53 in the whole of Galicia; Fig. 1), municipalities (315; Fig. 1) and parishes (officially, 3.772). In total, there are more than 30.000 rural hamlets, a pattern that has traditionally led to talk of a dispersed rural population. 


\begin{abstract}
"shows constant population loss due to an overwhelmingly aged population in its demographic structure, with a very low number of young and a highly negative natural balance. Economic prospects are based on shrinking farms [...] and external subsidies through retirement pensions" (Aldrey 2006: 32).
\end{abstract}

To overcome this critical situation, a rural development policy, of more than 20 years of uninterrupted history in Galicia, has been implemented through European Union (EU) funds. To this end, the province of Ourense has been especially targeted. This policy has not only been driven through the LEADER programme (or PRODER and AGADER in the Galician case, both equivalents to LEADER), but also through the ERDF regional funds. Most reviews on the incidence of such rural and regional development funds in Spain are positive - see, for instance, García-Rodríguez et al. (2005), Plaza (2005), Molinero et al. (2004) or Doval (2002). Nevertheless, literature shows a less favourable perception in Galicia. For example, Lois (2004: 114) has spoken of a "very poor management of EU funds" and Trabada (2007: 460) has noted that these programmes have been appropriated "by the local authorities and interested groups linked to political parties, which have guided actions towards municipal infrastructure and facilities", but with uncertain effects on the real economy. Tourism in Galicia has been conceived as a choice strategy within the paradigm of rural and regional development (Santos 2012, Santos and Paül 2011, Lois and Santos 2004). Notwithstanding, there is an agreement on the excessive weight given to the said mechanism of development. Moreover, there are many voices pointing to its plausible failure, evidenced by the very low annual occupancy in rural tourism accommodation businesses (below the threshold of profitability) and the suspicion of the fraudulent use of these funds destined for business creation (in the hands of entrepreneurs), which eventually have been destined to the rehabilitation of private homes.

Given this bleak picture that affects the state of rural areas and development policies, the aim of this paper is to refine the negative interpretation at regional scale by analysing two specific cases. Both share the fact that they have not been proposed or implemented by the political-institutional system, rather, both have emerged from civil society. The two initiatives under consideration are the following associations, self-proclaimed "rural development centres": O Viso (in the hamlet and parish of Lodoselo, municipality of Sarreaus, district of A Limia) and Portas Abertas (in the hamlet and parish of Arzádegos, municipality of Vilardevós, in the district of Val de Monterrei) (Fig. 1). The two cases are located in south-eastern Galicia (the province of Ourense), a region that is considered to be the most critical in Galicia. Through detailed observation of these cases, we obtain a richer view of the complexity of rural Galicia, which is commonly interpreted as being under the simplistic umbrella of the dominating general depression. There are few case studies on local experiences in Galicia such as those that will be the subject of attention here, so that, through this contribution, we aim to contribute to filling the gap.

The remainder of this paper is organised as follows. The next theoretical section sets out a conceptualisation on development, leading towards endogenous development, the core notion in this research. This is followed by an explanation of the adopted methodology, which is two-fold: quantitative for a regional analysis of the province of Ourense and qualitative for examining the particular case-studies. The paper then turns to outline the regional setting and the case-studies analysis results. The text concludes by discussing the empirical findings and exploring the implications of both experiences in terms of rural development. 


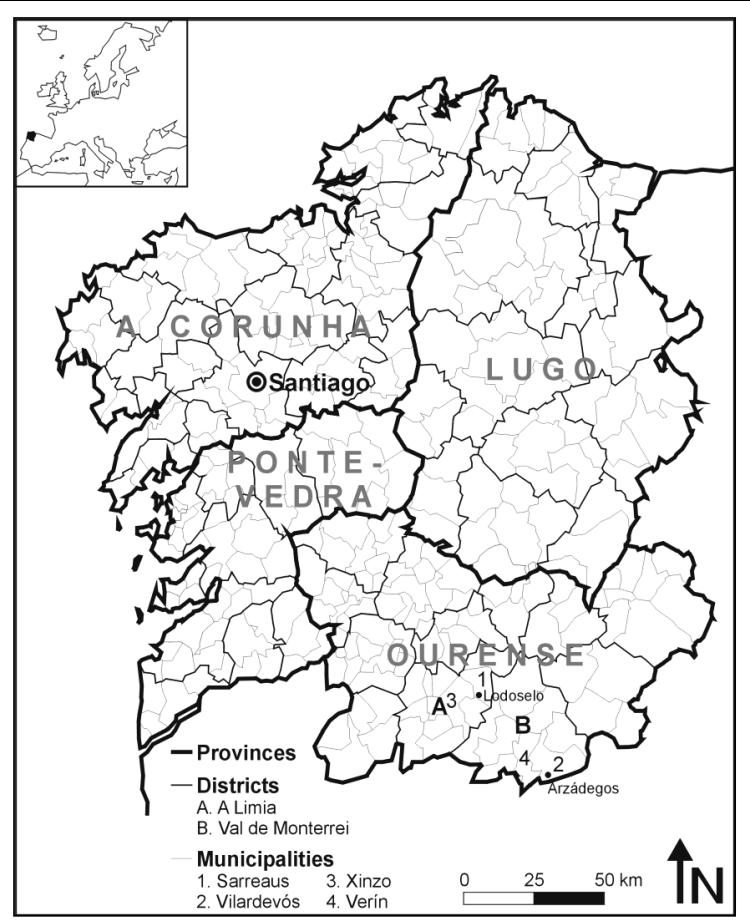

Fig. 1 - Location map of the study area

\section{Current notions of development}

There appears to be a high degree of consensus over the difference between the notions of development and growth (Brinkman 1995). Growth is understood as an increase in physical quantities, while development is the progress in skills, qualities or potentials (Ojeda 2003, 2004). "Given the linear nature and quantity of growth, development is a multidimensional concept - quantitative and qualitative at a time - that incorporates the principles of balance in distribution, autonomy in decision making, quality of life, creativity, level of enjoyment and so on" (Ojeda 2003: 54). Indeed, that economic or population growth (quantitative aspects) happens in a particular region or country does not automatically imply that it leads to development (qualitative aspect). In fact, sometimes the need for growth can compromise or destroy the pillars of a culture, with which "development" would actually mean a deceptive and isolated growth (Ojeda 2002). The decoupling of these notions has been expressed by Pike et al. (2007: 1260), as follows: 'Localities and regions can experience 'development' in quantitative terms [growth] but with a problematic qualitative dimension [...]. Similarly, localities and regions can witness qualitative 'development' that is quantitatively problematic". In reality, it is difficult to have any developed society or region without any growth (Galdeano-Gómez et al. 2011), although the latter must be at least socially and geographically distributed for the former to happen (Ojeda 2003, 2004). This is usually known in European technocratic terms as "social cohesion" and "territorial cohesion", respectively (Davoudi et al. 2009). Indeed, Haslam McKenzie (2013) has demonstrated that experiencing high economic growth rates in a given region does not mean development for communities in this region. 
Following this conception, development seems impossible if the population has no self-esteem, if inhabitants do not identify with their landscape, if there is no maintenance of their own identity and no sense of being part of a community, if there is not any show of living cultural specificity, no respect for inherited traditional knowledge and heritage, etc. (Markantoni et al. 2012, Ojeda 2003, 2004, Ray 2000a). "'Development' (whatever the term means) works best if the orthodox expert-designed-and-evaluated model is exchanged for one that emphasises the humanistic, dynamic and contextual possibilities of development. [...] Development [...] is an on-going dialogue, experiment or multiple exploration" (Ray 2000b: 451-452). This line of thought on development abounds in Latin America, with quite consistent standpoints - see, for instance, Vázquez-Barquero (2009) or Capalbo (2008).

Departing from this significant distinction, the popular notion of sustainability is much more related to the concept of development than to that of growth. Indeed, sustainable development is, according to the reputed Brundtland report, "development that meets the needs of the present without compromising the ability of future generations to meet their own needs" (World Commission on Environment and Development 1987: 43). This definition implies intergenerational solidarity and collective responsibility, issues that are qualitative and hardly reduced to rates, ratios or formulas. "For many scientists the authentic contradiction is only given in the meaning of sustainable growth, based on the philosophy of continuous growth, while the concept of sustainable development is considered more congruent" (Anton and Gonzàlez-Reverté 2005: 49). Naredo (2007) has summarised it in an axiom "unsustainable growth, sustainable development", and Mikkelson (2013) has reported how growth leads towards greater levels of resource consumption and waste production, and thus inequality and unsustainability.

Sustainable development is necessarily inclusive and covers a wide range of issues, according to the evolution of development ideas since the 1970s, from a historically dominant focus upon economic development, towards embracing social, ecological, political and cultural concerns (Pike et al. 2007). This contradicts a significant body of literature on rural geography that conflates sustainable development into economic growth. In this context and in times of the current global crisis, the timely theoretical proposals for degrowth, non-growth or serene degrowth as "alternatives" share a critique of the notion of growth and the need to focus on the idea of development, as respectively defended by Taibo (2009) in the Spanish-speaking world, Jackson (2009) in the Anglo-Saxon world or Latouche (2007) in the Francophone world.

The application of the notion of development across rural areas in the $\mathrm{EU}^{2)}$ from the Commission's milestone paper The Future of Rural Society (1988) eventually led, since its establishment in 1991, to the beginning of LEADER ${ }^{3)}$ policies and, to a great extent, the perception of tourism as a solution to rural development (Böcher 2008, Lois and Santos 2004,

2) Practically speaking, in the EU context, regional and rural development policies have "conflated" (Woods 2005: 145).

3) Acronym for Liaisons entre actions de développement de l'économie rurale, it constitutes a European initiative launched in 1991, given that the Commission acquired the power to introduce its own pilot interventions (so-called 'initiatives') in 1988. It had three phases (LEADER I, 1991-94; LEADER II, 1994-99; LEADER+, 2000-6) where specific rural regions were selected to encourage development projects and actions based on local strategies, allegedly driven by participative partnerships on the ground consisting of community associations, businesses, public sector bodies, etc. In the period 2007-2013, the LEADER approach has been integrated into the official rural development programmes (RDPs) of all the regions of the Union, a change of reference frame that has been labelled as "LEADER mainstreaming" (Dax et al. 2013); it has been argued that in this latter period the LEADER as it used to be has been diluted. In any case, this EU initiative has attracted considerable academic attention (High and Nemes 2007). 
Ray 2000a, Woods 2005). "The most accepted trend over the last two or three decades in European rural development policy [...] (for example, the LEADER programme) has been to promote increasing diversification in order to accommodate various economic activities" (Galdeano-Gómez et al. 2011: 56), in a shift that has commonly been coined as "from production to consumption" (Marsden 1999, Scott et al. 2011, Woods 2005, Ray 2000a). The transition from a rural economy based on agriculture to a diversified economy has been widespread - that is, the multifunctionality or pluriactivity paradigm (McDonagh 2013, Wilson 2007, Plaza 2006, van der Ploeg et al. 2000, Marsden 1999), despite having received severe criticism (Evans et al. 2002). There is an ongoing debate on the role the farming sector should play in rural development (among others, Galdeano-Gómez et al. 2011 or van der Ploeg et al. 2000).

On the one hand, the majority of opinions point to the need to address the challenge by giving a pivotal role to tourism - several authors are reported in this respect by Markantoni et al. (2012). In short, "rural development is multi-facetted in nature. It unfolds into a wide array of different and sometimes interconnected practices. Among them are landscape management, the conservation of new nature values, agritourism [...]", given that "there is an entrenched assumption that the agricultural sector is incapable of generating rural renewal" (van der Ploeg et al. 2000: 394, 401) and that "the focus on agriculture as the main activity [is] misleading" (Galdeano-Gómez et al. 2011: 57). Some scholars have even argued that the future for the countryside is "in many ways post-agricultural" (Halfacree 1997: 72). In other words, under this perspective, "Rural areas have to make use of other potentials [rather than agriculture] for development, such as their recreational value for urbanites or their natural beauty to attract for tourists" (Böcher 2008: 378).

On the other hand, some of the current literature tends to argue that the agricultural and livestock sector must remain the core (for a review of these opinions, see McDonagh 2013) and activities such as tourism should be complementary, not dominant. In this sense, it has been said that "the new economic activities to give impetus in regressive rural areas should be based to a great extent, and contrary to many theories on development, strengthening agriculture, livestock and forestry sectors" (Lois 2004: 125). That is to say "rural development can be constructed very effectively by using the innovativeness and entrepreneurial skills present in the agricultural industry itself" (van der Ploeg et al. 2000: 401). Therefore, this perspective gives room for a "new position for agriculture" through "viable agricultures [contributing] to maintain viable rural communities" (Banks and Marsden 2000: 466).

Overall, the literature on rural development focuses on the analysis of the intervention by national (and sub- and supra- national) administrations (Dax et al. 2013, Rodríguez-Pose 2013, Böcher 2008, Plaza 2006, Ray 2006, 2000a, 2000b), either to criticise or to praise, or to explain what has been done or what should be done. In fact, van der Ploeg et al. (2000: 396) and Ray (2000a: 85) have detected that rural development "has become part of political discourse" and most of the literature is devoted to considering this domain. There is some contradiction between this mainstream literature and our outlined theory on development. Indeed, if in this notion local potentials (resources, human capital, and so on) are central, why focus on the investments that are made by the public sector through funds coming from outside local communities? In this respect, Lois and Santos (2004: 142) have speculatively formulated the idea of spontaneous development, which refers to those processes that improve the quality of rural life, beyond that of public authorities. In a more founded line of thought, VázquezBarquero $(2006,2009)$ has reported on endogenous development. This concept is shared with a long list of authors from its origins set in the 1970s and, since then, several perspectives to this respect have been generated but have not always coincided (Galdeano-Gómez et al. 2011, Vázquez-Barquero 2006, 2007). 
Basically, endogenous development offers an interpretation of development from the local communities, not for the local communities, and sees civil society and local stakeholders as having a key role in generating development. "Endogeneity [...] is based [...] on a critique of an over-dependency on, and vulnerability to, development designed and controlled by 'extra-local' forces" (Ray 2000b: 447), and thus "sees the key challenge as valorising difference through the nurturing of locally distinctive human and environmental capacities" (Galdeano-Gómez et al. 2011: 59). Therefore, endogenous development is "constructed from economic, social, environmental, institutional, political and cultural factors that are uniquely combined in each locality, and in each region", for that reason "upholding that development initiative differs from one area to another, from one locality to another" (Vázquez-Barquero 2007: 206). According to Ray (2000a, 2000b, 2006), Garofoli (2002), Woods (2005) or Gkartzios and Scott (2013), endogenous models of development search for resources and mechanisms that focus on the local territorial level, and they emphasize local participation and control.

The above mentioned EU LEADER initiative has allegedly been framed on the endogenous approach (Furmankiewicz et al. 2010, Böcher 2008, High and Nemes 2007, Ray 2000a, 2000b, 2006), given that LEADER policy-makers defend that endogenous potentials of rural regions are the basis of rural development strategies. However, there is considerable debate as to what extent endogenous development may be turned into policy prescriptions and actions, given that it is basically spontaneous and, in this sense, endogenous development policies seem to be more aspirational than operational, or even rhetorical or heuristic (McDonagh 2013, High and Nemes 2007, Ray 2006). This discussion in line with the approaches asserting that there is no 'one-size-fits-all' development model or template (Rodríguez-Pose 2013, Pike et al. 2007).

In order to precisely understand how the LEADER approach is being practically implemented, Ray $(2006,2000 a)$ has proposed the concept of neo-endogenous development. The nuance from the notion of endogenous development is that the neo-endogenous approach acknowledges various manifestations of the 'extra-local'. Neo-endogenous is "a new term [...] shorthand to describe endogenous-based development in which extra-local factors are recognised and regarded as essential but which retains a belief in the potential of local areas to shape their future" (Ray 2000a: 4). In other words, the neo-endogenous accepts that there is a scope for the exogenous interventions that "inevitably and crucially impact on - and are exploitable by - the local level" (Ray 2006: 281). This is based on the fact that, although endogenous is supposed to be the contrary of exogenous (High and Nemes 2007, Pike et al. 2007, Garofoli 2002, Ray 2000a, 2000b) they "should not be interpreted as mutually exclusive categories" (Furmankiewicz 2011: 265). As defended by Galdeano-Gómez et al. (2011: 61), "any locality will include a mix of exogenous and endogenous forces, and the local level must interact with the extra-local", the latter also being called "global" by Garofoli (2002) or Ray (2000a, 2000b). Therefore, the neo-endogenous approach to rural development is a hybrid model between exogenous and endogenous as ideal opposites - that is, a simple dualism multi-scalar in nature (Gkartzios and Scott 2013, Galdeano-Gómez et al. 2011, Ray 2006). In short, it basically answers 'yes' to the question posed by High and Nemes (2007: 114): "is it [so] that endogenous and exogenous development cannot be reconciled?".

This train of thought tends to relate to the notion of governance that, unlike government, takes into consideration the role of business and civil society in the exercise of power and, thus, goes beyond the formalities of politics (Stoker 1998). However, Böcher (2008: 372, 377) points out that the concept of governance holds "some kind of confusion" or it is "relatively imprecise". Generally speaking, governance refers to various parties working together through networks in order to achieve common goals, while government reserves itself to traditional forms of public action operated by the apparatuses of the sovereign state (Böcher 2008, Stoker 1998). In this 
sense, governance is usually conceived as bottom-up, while government is defined as hierarchically top-down. However, governance is also referred to at times as a multi-scalar or multi-level process, which means that different governmental and non-governmental actors on several tiers are engaged in the dynamics of participative negotiation (Gkartzios and Scott 2013, Romero and Farinós 2011, High and Nemes 2007, Pike et al. 2007, Woods 2005, Marsden 1999). In this respect, Gkartzios and Scott (2013), Romero and Farinós (2011), Böcher (2008), High and Nemes (2007), Ray (2006, 2000a, 2000b) and other scholars have shown how top-down government and bottom-up governance dynamics interact and are combined on the ground, even leading to conflicts.

It is worth mentioning that the governance idea is somewhat self-serving as it tends to conceal the role of the public sector, which has been very pleasing to the prevailing neoliberal environment in western countries since the early 1980s (Furmankiewicz et al. 2010, Tonts and Haslam McKenzie 2005, Woods 2005, Ray 2000a, 2000b). In any case, the so-called territorial governance is an extended paradigm in geography (Furmankiewicz 2011, Romero and Farinós 2011, Farinós 2008) and allows for the role of civil society processes of development to be underlined, particularly the endogenous ones. "In territorial governance the effect of collective management of resources is an important issue. The enhancement of interactions between local stakeholders is considered as the first condition for a long-term cooperation" (Furmankiewicz 2011: 263).

In conclusion, and as a systematisation of everything stated, development can be defined as follows:

"A consensual, democratic definition and search for the common good, including future generations to ensure the value of sustainability and put a restriction on speculative growth. [...] Collective social learning and political processes can lead to legitimate, crafted, generally good decisions. Everything needed to counteract speculative growth linked only to values of economic growth [...]. Hence, it is essential to place sustainability as a starting element linked to deliberative participation." (Sánchez-García 2007: 49).

\section{Methodology}

Two data collection methods are adopted for this research: statistical database processing and qualitative information analysis. Firstly, the quantitative approach allows for characterising the situation of the regional context where the two case-studies are located. Initially, we seek to contextualise the further examined specific experiences, that is, to create a general overview of the rural areas in south-eastern Galicia. Secondly, the particular case-studies examination is developed through a qualitative approach which is suitable to understand what people perceive as important from their individual perspective (Eyles and Smith 1988, Taylor and Bogdan 1984).

This dual approach, both qualitative and quantitative, depending on the scale, is rooted in their methodological complementarity through triangulation (Bericat 1998). In fact, the procedure of combining macro-geographical statistical indicators with micro-geographical qualitative approaches is quite common in geography, given the weaknesses of quantitative studies at the level of small groups (Bailly 1987). Likewise, Bessière (2012: 23-24) has argued that the analysis of rural areas strictly based on quantitative terms is "too reductive", thus it has to be complemented by a "more qualitative approach" at community scale since the "local enrolment acts as a basic feature in rural societies". In this respect, Marsden (1999: 508) has advocated 
in a seminal work on rural geography that "[o]ne important concern is how the trends outlined [i.e. at regional scale] [...] manifest themselves locally". In our study, departing from the critical situation of the rural areas of the province of Ourense at regional scale, the performance of two local case-studies in terms of development is investigated. Particular inspiration for this two-fold methodological approach has been obtained from Dax et al. (2013) and Haslam McKenzie (2013).

Qualitative analysis has comprised documentary and interviewing sources. With regard to the first technique, primary sources (association brochures, websites ${ }^{4)}$, etc.) and secondary sources (already developed research, newspapers, etc.) have been extensively examined. In relation to interviewing, from 2007 to 2009, several field trips to the case-study areas (hamlets, municipalities and districts) were conducted, including semi-structured interviews with one of the stakeholders in each case in order to obtain their views on the experience. "The emphasis is on considering the meanings people attribute to their life and the processes which operate in particular social contexts" (Valentine 1997: 111). A script with an open set of subjects and questions without any fixed response pattern categories was used for the interviews. The aim was to provide empathic interaction and even detailed feelings and valued judgments from the interviewer (Ruiz-Olabuénaga 2003, Eyles and Smith 1988, Taylor and Bogdan 1984). The information was enriched with fieldtrip visits with students in 2007 and 2008, in which open debates were generated (between students, those in charge of the experience and lecturers), thus complementing the previous ideas. These techniques have improved the understanding (rather than the explanation) of the development experiences in the hamlets, and thereby systematising:

- The reasons given for the initiative's origin and its permanence.

- Their idea of development in each case, related or not to tourism.

- Activities, experiences, results, etc. they consider being the most outstanding.

- The project's relationship with institutionalised development (governments, etc.).

- Territorial links established on different scales.

These are the key themes considered in the analysis. We do not provide systematic dialogue transcripts, except some short sentences, because they were not recorded (one option of qualitative work according to Eyles and Smith 1988). However, we did take down our impressions in a notebook. We must clarify that we did not seek to point out the socioeconomic impact, hamlet acceptance or the level of satisfaction from the experiences, issues that deviate away from the purpose of this article. Why $O$ Viso and Portas Abertas? They were chosen for the implementation of the purposive sampling strategy or "snowball", as explained by Hay (2005) and Ruiz-Olabuénaga (2003). In fact, the qualitative methodology does not attempt a statistical representativeness, but it does try to go deeper into each case (Hay 2005, Ruiz-Olabuénaga 2003, Eyles and Smith 1988, Valentine 1997, Taylor and Bogdan 1984).

4) http://www.cdroviso.org/ and http://www.cdrportasabertas.org/ (Consulted in October 2013). 


\section{Results}

"Is anybody there?"5) The regional setting: the rural areas in the province of Ourense

In this section, we review some indicators that describe the situation of rural areas in the southeastern Galicia region, that is, the province of Ourense. Firstly, with regard to demography, it is noteworthy that this province is one of the few of the total of 50 Spanish provinces which exhibits decades of sustained decrease (Goerlich and Mas 2006). Fig. 2 represents the last century's demographic curve. After an historic high in the 1950 Census, the region has been continuously declining and has gone from nearly 470000 to just over 330000 current inhabitants. This trend can be completed with two proportional facts: the province accounted for $1.7 \%$ of the Spanish population in 1950 but it remained at $0.7 \%$ of the total in 2011 , so while Ourense fell Spain rose from 28 to 47 million inhabitants. In the same period, Galicia has stagnated (remaining at 2.7 million), but, with Ourense's decrease, the province went from representing within it a percentage of more than $17 \%$ to less than $12 \%$.

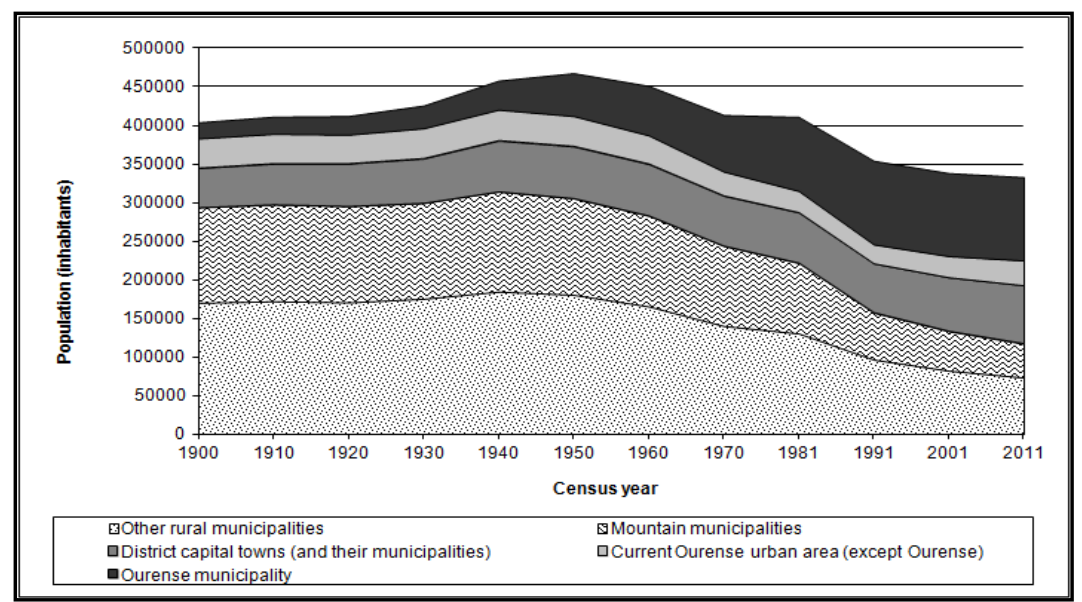

Fig. 2 - Demographic evolution of the province of Ourense (1900-2011) Source: www.ine.es

Fig. 2 also provides relevant geographical information showing what has become of a spatial redistribution of the population. The current rural municipalities (both from the mountainous areas $^{6)}$ and the other rural areas) represented more than $73 \%$ of the provincial population at the beginning of the century, a percentage that was higher considering that the remaining $27 \%$ was also largely rural (but we do not have the infra-municipal data). Nonetheless, that $73 \%$ decreased to $35 \%$ in 2011. In a dynamic turnabout, the municipality of the city of Ourense has increased from $5 \%$ to over $32 \%$. The municipalities around the provincial capital, which are now peri-urban areas, but were not at the start of the $20^{\text {th }}$ century ${ }^{7)}$, have remained stable at $9-10 \%$; throughout the $20^{\text {th }}$ century, these current peri-urban areas behaved as rural, losing population, but in the last few decades they have regained importance through the neighbouring expansion

5) In Galicia there is an expression that has become a symbol for rural depopulation, thanks to the documentary Queda alguén aí? ('Is anybody there?') by Rafael Cid (2007).

6) We define as mountainous municipalities those considered as such by Torres et al. (1993).

7) We consider those municipalities defined as part of the urban area of Ourense under the passed Directrices de Ordenación Territorial ('Regional Planning Guidelines of Galicia') in 2008 (later revoked); the city of Ourense itself is excluded. 
of the city of Ourense. Finally, the district capital towns ${ }^{8)}$ show a population increase (from 13 to $23 \%$ ), to the extent that they have now become small cities acting as focal nodes of rural areas (Rodríguez-González 1999). In short: the province is now urban and its rural areas are practically empty.

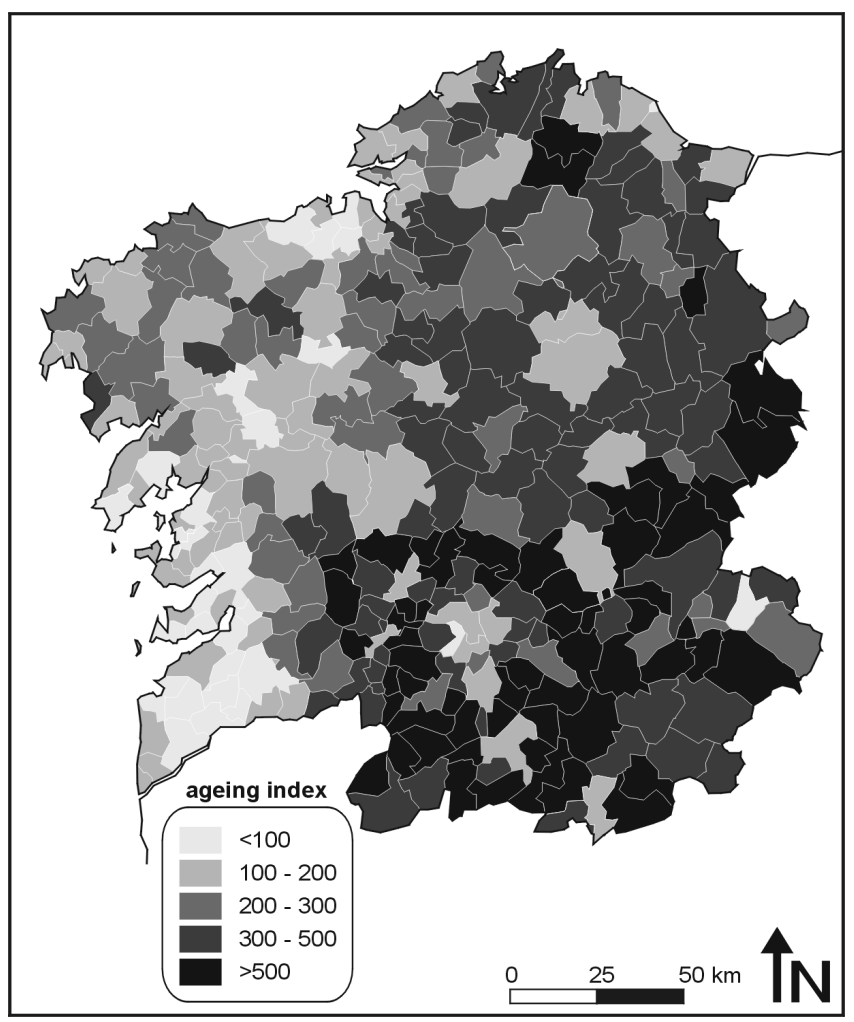

Fig. 3 - Ageing index by municipalities in Galicia (2011) Source: www.ige.eu

Nevertheless, the gap tends to deepen as the ageing in the rural areas of the province has reached exorbitant values. A few years on the horizon, and given that it is unlikely that a mass arrival of migrants occurs, there may be absolute depopulation. In Fig. 3, we can see how ageing (measured by the rate of ageing or the relationship between the young and the old population) affects the entire province, except for 2 municipalities (out of a total of 92), in which there are more younger than older people. Indeed, ageing displays chilling magnitudes in many municipalities. Lobeira and A Teixeira present the highest ageing rates in Galicia, with 461 elderly for every 16 youngsters and toddlers in the first, 224 for every 20 in the second. Such alarming rates can only lead to the mid-term demographic extinction of those municipalities (López-González 2004).

8) We include the municipalities of the regional cities in accordance with the 2008 Regional Planning Guidelines, although we detract 5 municipalities as we consider them completely rural. 
In any case, the rural crisis in the province of Ourense cannot be reduced to demographic issues. By means of an indicator that we have developed (the number of companies per $\mathrm{km}^{2}$ ) it is clear that economic activity in most of the south-eastern Galicia region is at its lowest ebb, with less than one company per $\mathrm{km}^{2}$ (Fig. 4). In most of the province of Ourense, there is, as a rule, less than 100 economic activities in each municipality. This figure - considering that this also includes the self-employed people - shows the almost absolute economic stagnation found in these areas.

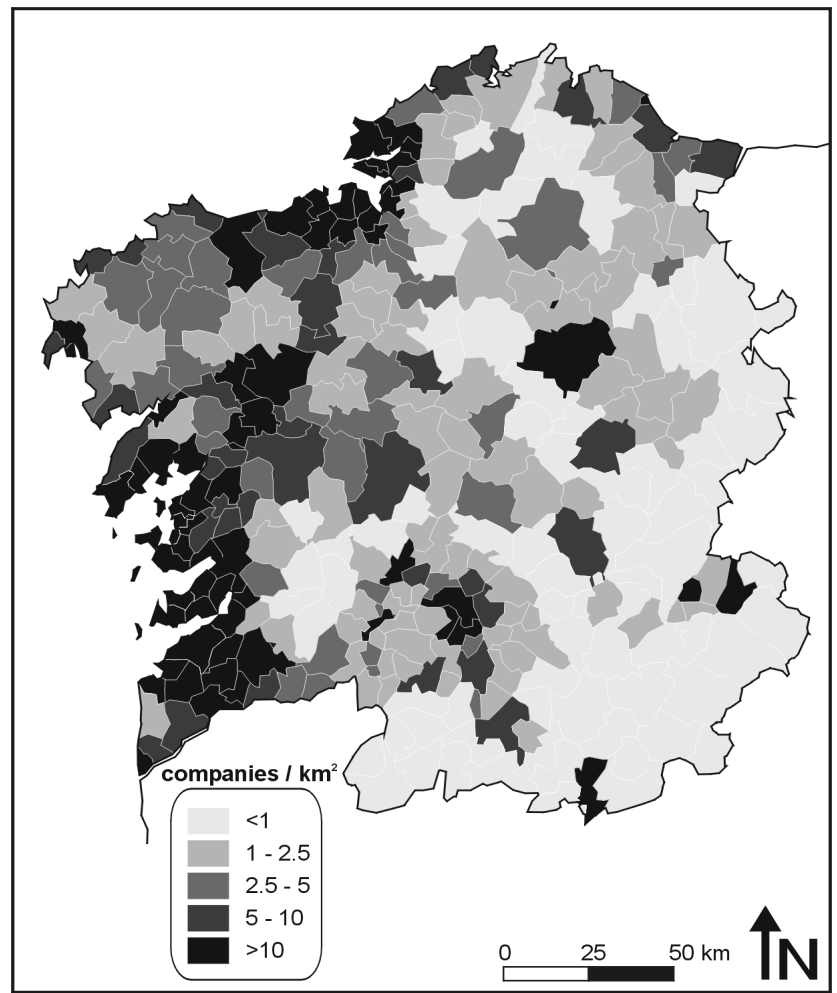

Fig. 4 - Density of economic activities by municipalities in Galicia (2011) Source: www.ige.eu

In particular regard to the economy of farming, which is the traditional breadwinner in rural areas, the municipalities of Ourense again show ailing values. As noted by Majoral (1997), it makes more sense in the analysis of farms to consider the economic or employment dimensions than that of physical (area of land per farm). Workforce data is a good indicator of the health of agriculture as this allows for actual work being carried out in farms by means of units so-called yearly work units or YWU (Molinero et al. 2004, Majoral 1997). In Galicia, and as it can be seen in Fig. 5, Ourense is the province with less YWUs (14\% of total). The province of Lugo, in contrast, has $34 \%$ of the Galician YWUs, despite having a similar population to Ourense (333.257 inhabitants in the province of Ourense and 351.530 inhabitants in Lugo, in 2011). This fact leads us to infer that agriculture in south-eastern Galicia has been scaled down and kept at a low, in a marginal or subsistence situation. Many rural municipalities in other Galician provinces have a high rate of ageing (Fig. 3), but, at the same time, a high concentration of YWUs (Fig. 5), whereas agricultural inactivity is an added headache to the 
extreme ageing problem in the province of Ourense. This fact implies a critical situation for both demographics and for the traditional rural economy in this region.

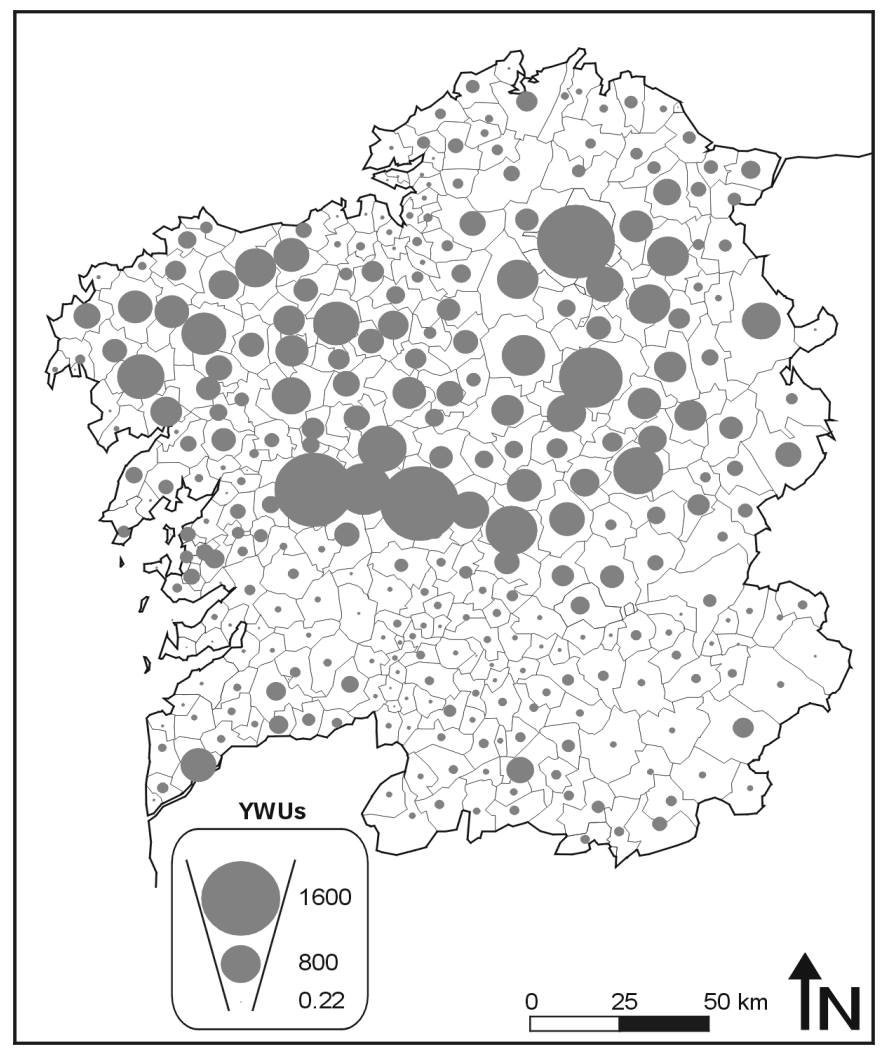

Fig. 5 - Agricultural workforce by municipalities in Galicia (2009) Source: www.ine.es

Given these conditions in agriculture, tourism is always treated as the alternative sector to the crisis in the agrarian economy (Santos 2012, Santos and Paül 2011, Lois and Santos 2004). Once again, we see how weak the introduction of economic activity, tourism in this case, is in the rural municipalities of the province of Ourense (Fig. 6). Only 85 of the 592 rural tourism accommodation businesses in Galicia are in the province of Ourense while in the province of Lugo, with practically the same population as the former, there are 156 . Thus, the tourism as an "alternative" for rural and regional development is extremely feeble in the province of Ourense. At the same time, the complementarity between agriculture and rural tourism in the form of farm tourism or agritourism (rural tourism accommodation businesses type $C$ in Galician regulation) is almost nonexistent in Ourense. In fact, there are only 2 type C-businesses, unlike other areas of Galicia, where this rural tourism type is dominant (Fig. 6).

In short, rural areas in the province of Ourense present a frail and declining demography, with extreme ageing putting them at risk of extinction. Economic activities are meagre in both farming (which is marginal) and tourism; neither really seems to offer an alternative to regional 
economic decline. In the apparent lost hope for rural areas in this province, there lie two divergent cases that we will examine in the following sections.

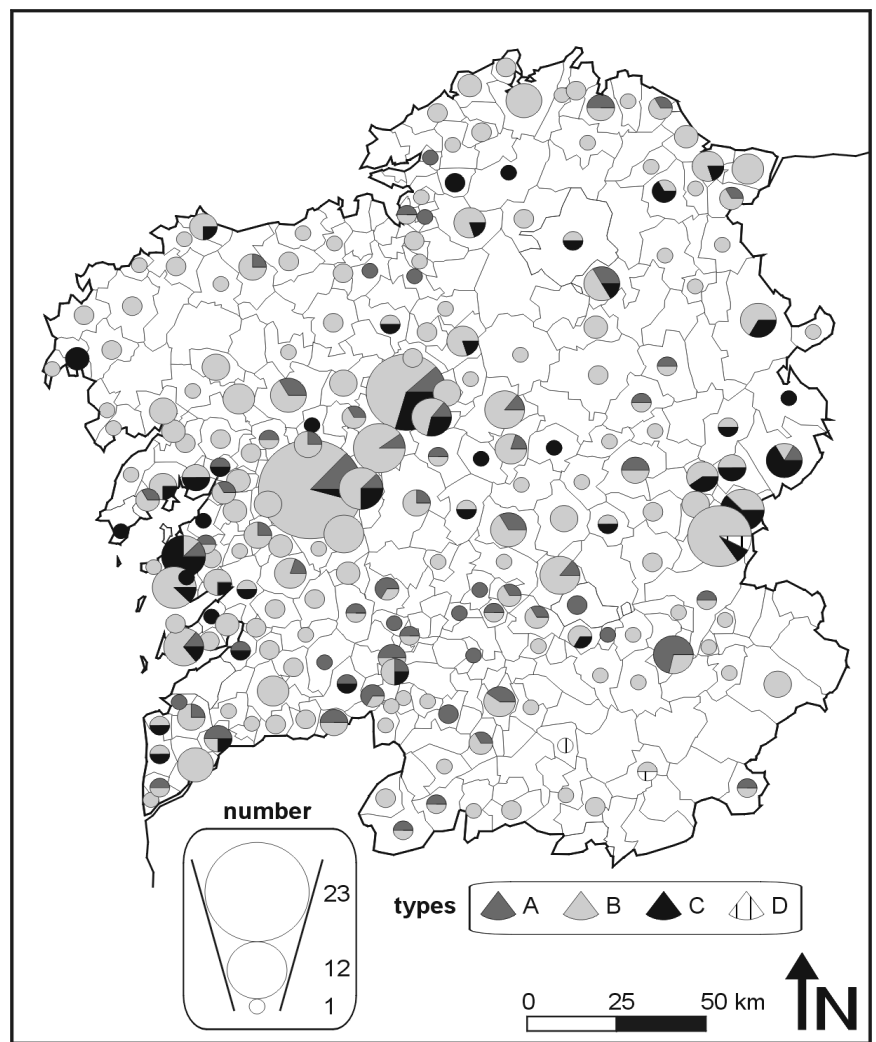

Fig. 6 - Rural tourism accommodation businesses by municipalities in Galicia (2013)

Source: www.turgalicia.es

\section{O Viso Rural Development Centre}

O Viso's origin lies in a previous association that was created in 1985 with the aim of activating the parish of Lodoselo. Through the rehabilitation and reuse of a number of abandoned components and buildings, which were mainly in disuse due to emigration (the community oven, the community wash house, an abandoned forge, a closed school, etc.), they report that they attempted to give new life to a common heritage and, in this way, place value on the hamlet's own culture, identity and self-esteem. The initiative was not only limited to the restoration and reuse of real estate, but also extended to the reintroduction of festivals like the Magosto (All Saints' Eve) or Entroido (Carnival) - collective celebrations that had been lost over time. This was all done through contact with the local community and recovery of the traditional ways of doing things. In 1990, the association decided to become an NGO and set more ambitious targets, developing its own rural development programme: joining diverse initiatives, becoming a space for dialogue and collaboration, promoting culture and information and so on. It should be noted that $O$ Viso contributed to the founding of COCEDER 
(Confederación de centros de desarrollo rural, 'Confederation of Rural Development Centres' in Spain) which, given its scope, receives funds from the Spanish Ministry for Social Affairs through participation in the consignment of $0.52 \%$ of income tax ${ }^{9}$. O Viso currently counts on 200 members or so.

In 1993 began (and continues to date) the Pobo Escola ('People School') programme, which is very popular in the district of A Limia and even in the province of Ourense. This activity requires that the elderly people of Lodoselo teach local schoolchildren, or from further afield, different rural cultural elements: trades (leather, linen weaving, basketry, charcoal, etc.), bread making (making bread in the community oven then taking it home), organic gardening and so on. They do not aim to develop conventional workshops, but living museums in which the protagonists are the residents. Through their own feelings and words, the elderly explain countryside activities and create an intergenerational communication channel. For the hamlet, Pobo Escola is a mechanism to dignify its very nature. Even though some people from Lodoselo had been reluctant about $O$ Viso activities at the beginning, the Pobo Escola programme has brought many older people on board and these people have even loaned materials, tools and so on from their homes. The initial idea from $O$ Viso lies in the fact that there is already a Lodoselo culture, a rural culture of its own and that "there is no need to invent anything" but just expand on inherited identity, become aware, take pride in it and evolve it from there and go incorporating modern elements.

$O$ Viso restored the ruins and now manages the Lodoselo rectory, which was loaned, courtesy of the Diocese of Ourense, for 25 years. As a result, a hostel has been set up in the rectory that can accommodate between 15 to 40 people and accepts groups who want to stay and use the facilities (kitchen, rooms, etc.) as well as those who want to follow activities in the Pobo Escola programme or even accept others, including those on hiking, biking routes and so on for several days. The hostel's guest profile is very ample, from schools and youth groups to bachelor parties, social education students or groups of foreigners who want to enjoy the Lodoselo experience. Being an NGO, reasonable prices are charged and since no profit is sought, proceeds go towards the maintenance of other $O$ Viso activities.

Started in 1994 as the product of an agreement between O Viso and the Municipal Council of Xinzo, the Youth Information Centre (Centro de Información Xuvenil, CIX) in Xinzo (district capital city of A Limia; Fig. 1) was created. The centre's basic objective is not only to satisfy the cultural concerns of the district's youth, but also to form a network of volunteers (with branches abroad), to offer a youth job bank, to contribute to youth entrepreneurship and give information on sexuality and drugs. All this information reaches the public through a small newspaper that has become popular in the region. From CIX Xinzo, they also manage a leisure time programme in Lodoselo with a wide range of courses (monitors, environmental education, theatre, sexuality and so on).

Not only do they seek to serve the youth but also older people in Lodoselo and the surrounding area. For this purpose, a community soup kitchen was installed in the rectory building in the late 1990s, where about 40 people lunch accompanied each day. The $O$ Viso elderly are offered laundry and ironing services, transportation to the health centre, the purchase of medicines, and so on, all paid depending on each person's pension. O Viso pioneered the offer of these services in rural Ourense although some municipal councils have since followed suit.

9) The income tax in Spain is so-called IRPF (Impuesto sobre la renta de las personas físicas, 'Personal Income Tax'). If the contributor agrees, the government destines $0.52 \%$ of their income to the Catholic Church or to social purposes (NGOs). Given that COCEDER is Spanish-wide established, it is a potential receiver of such funds, together with other NGOs. 
The resources for this type of activity, called A túa outra casa ('Your Other Home'), come from end user contributions, from $O$ Viso funds and agreements with institutions. The most ambitious $A$ túa casa activity has been the opening of supervised community housing in 2002 , in part made possible by the European LEADER programme, which granted funds for the construction of the building. Applying the same philosophy as the soup kitchen, each person is charged depending on their capabilities to pay. The objective of community housing for elderly people, who wish to and are in a delicate situation, is that they can move in and live there, with the confessed will to "guarantee the right to die where one had lived" - i.e. to remain in the hamlet in old age. With so many actions taken, it should be noted that $O$ Viso became the largest net employer in the municipality of Sarreaus without being a business ${ }^{10}$. While acting for elderly people, the position of therapist who travels to homes and who began to work in Lodoselo and the surrounding areas must be highlighted and this service now covers the whole of the district of A Limia. It is relevant to point out that the work of this person is financed by a non-profit foundation from the private sector, which goes towards alleviating dependence on the authorities and diversifies resource sources.

O Viso has a clear commitment to promoting the development of agriculture in the region. In this sense, it constantly collaborates with organic farming activities (with a cooperative, for example), which has brought a gardening activity to Pobo Escola and has used the country's grain (corn and rye) to make bread. In the same way, and based on the maxim expressing "if you stop, you die", mid-term work with livestock is being devised. In particular, the local type of cow in A Limia is being reintroduced into the surrounding hills of Lodoselo in order to avoid losing the breed and to minimise the risk of forest fires.

\section{Porta Abertas Rural Development Centre}

Portas Abertas (literally meaning 'Open Doors') started in 1990 after the concerns from the clergy in the area. They wanted to help the people in the district of Val de Monterrei to be able to stay in their place of origin and avoid their emigration. From the beginning they joined COCEDER which allows, as in the case of O Viso, access to Spanish governmental funds. An association was then formed (currently there are over 200 members) and it is legally recognised as a non-profit organisation with the aim of persuading people in the rural area to get involved in cooperation and voluntarism. They aim to undertake joint actions and support the promotion of disadvantaged social groups. The elderly represent a priority line of action as work is carried out to neutralise the cases of loneliness and the need to place the elderly in care homes. People always being isolated in their homes is reported as a danger and so Portas Abertas aims to forge social links and break this isolation. The declared purpose of the various actions is to "make a community" that the residents feel proud of being part of it and its traditions. Various activities are organised (cinema, looms, selective collections, etc.). Some of them are striking - as in the case of makeup workshops for the elderly, with very positive effects on individual self-esteem quoted. It also works with children in the municipality of Vilardevós by organising afternoons so youngsters can be together after school, they can interact with each other and not lock themselves away in their houses.

Surely the most visible action taken in the 1990s was the rehabilitation and re-use of rural schools that had previously been closed down. One of them became the headquarters of Portas Abertas in Arzádegos. Another one has become a rural hostel (Vilarello da Cota), where activities and accommodation (with kitchen, bathroom, heating, etc.) are managed in the 24-bed hostel. Since it does not meet any of the 4 legal categories of rural tourism

10) Information supplied by the Mayor of Sarreaus (December 2008), in a telephone conversation. 
accommodation businesses (Fig. 6), it works as place for social and cultural activities of various kinds, in which one may complementarily stay the night. To sign up, a programme of activities with Portas Abertas must be agreed: hiking, environmentally-themed workshops and so on. This hostel mainly welcomes groups of friends.

Portas Abertas left Arzádegos in October 2007, the hamlet where it was founded, and moved to Vilardevós, the village where the municipality has its capital. The reason was the willingness to take over the management of the Smugglers' Interpretation Centre, which was built with funds from the EU INTERREG programme and which was designed as a tourist attraction ${ }^{11)}$, as the Municipal Council of Vilardevós was not able to manage it due to a lack of funds for its maintenance. Thus, an agreement was reached between Portas Abertas and the Municipal Council for the association to be responsible for its daily management and to keep it open. In return, they were able to use the building as their headquarters. The Interpretation Centre has counted on some tourist infrastructure (promotional video, panels, etc.), but Portas Abertas has wanted to give it a coherent project, as well as keep it alive and make it a meeting place for the locals. According to the Mayor of Vilardevós, it was in danger of becoming a "dead centre" and, by way of an agreement with Portas Abertas, it was placed in the hands of citizens ${ }^{12}$.

Portas Abertas has worked for almost the whole district from the beginning. In conjunction with the Federation of Rural Women (Federación de Mulleres Rurais) of Ourense, a computer classroom was opened in 2003 in Verín (district capital city of Val de Monterrei; Fig. 1). Here, young computer experts teach computer skills to the elderly, as well as other groups, such as the disabled and immigrants. One building has also been restored in Verín and it is used as a social and family meeting centre for youngsters in dysfunctional families. The resources are obtained not just through participation in the $0.52 \%$ income tax fund, but also through agreements with public and private institutions (especially savings banks and foundations). Having said that much of the project is based on volunteer work and some actions are supported by government funds. For example, a programme to favour the integration of children from immigrant families (especially Romanian and Portuguese) was supported by the Galician government, a private foundation and a bank. Portas Abertas also participated in LEADER I (1991-93) and II (1994-99). In the first case, it directly managed funds and in the second it worked within the association that was established for this purpose. They prefer to raise funds from private sector than from public sector because there are fewer problems in its management. In any event, they stress their political independence from any party in power and they refuse to be linked to any party. The idea of Portas Abertas is to ask for funds when they have ideas, and not vice versa.

Their commitment to the primary sector stands out because they understand that tourism (hostel in Vilarello da Cota, Smugglers' Interpretation Centre in Vilardevós, etc.) has to be a complementary activity in rural areas. In their valuation of the farming sector, they have opted for chestnut growing on terraces by creating a company (helped by EU funds); they have

11) Within the framework of INTERREG III (2000-2006), it was decided to create a Smuggler's Interpretation Centre in Vilardevós, given the trans-boundary black marketer tradition in the area. It is a typical European funds "investment": costly restoration of an old building and the creation of an exhibition, based on information boards with the intention of placing it at the service of tourism, but without an operational project that can attract demand or proper insertion in the regional tourism system. This type of initiative leads to failure, commonly to closure and abandonment of the infrastructure.

12) La Región 11.10.2007. 
developed a proposal for the extension of Monterrei $\mathrm{PDO}^{13)}$ so that it covers the municipality of Vilardevós ${ }^{14)}$; they have conducted agricultural training courses on topics like cadastre or food/ wine tasting, all funded by the Galician Ministry for Rural Affairs; they have worked with the Provincial Council for the reintroduction of olive grove picking (1.600 trees in two communal forests) and, in parallel, there has been the creation of an exhibition and olive oil in the Smugglers' Interpretation Centre ${ }^{15}$.

\section{Discussion}

The two studied experiences respond to the concept of development identified by Ojeda (2002, 2003, 2004) or Markantoni et al. (2012). Indeed, they are based on elements such as the pursuit of self-esteem, the maintenance of identity or respect for inherited traditional knowledge and heritage. In terms of self-esteem, the intended and conscious use of the Galician language in the two case studies is highly revealing. In both cases, it was claimed that rural development is impossible if the language of Galicia is foregone - in fact, one of the association's most active members is not a native speaker, but has wholeheartedly adopted the language. In the same way, the spoken pride of living in the countryside should be stressed, and the desire to continue in that same vein, as is noted in the slogan of Portas Abertas: "Rural, naturally!" ${ }^{\circledR}$. In an almost ceremonial way, both initiatives started through a rehabilitation phase of unused material elements (the abandoned rectory, collective oven, closed-down schools, etc.). Nevertheless, these actions have transcended the tangible dimension in such a way that they have helped people to (re)identify with their local area and have somehow become symbols for rural life by showing that tradition and history do not belong only to the past but also to the present and future, in line with the "culture economies" of Ray (2000a) when theorising on endogenous development.

Moreover, the two initiatives advocate a particular direction of rural development with regard to the ongoing discussion on the role of agriculture. From our previous analysis, we can deduce that the primary sector is placed at the centre of proposals: chestnuts, olives, or vineyards in Portas Abertas; organic farming, livestock or native cereal grain in $O$ Viso. This choice is consistent with Lois' (2004) or Banks and Marsden's (2000) academic propositions in this respect. It is, in any case, about agriculture not being seen as productivism, but as logic of what Ilbery and Bowler (1998) have called "post-productivism" or Wilson (2007) "no-productivism". As a protagonist from Lodoselo commented, "The countryside cannot live without farmers and breeders; the rest will come later and not the other way round, as is being done". This interviewee's quote is as forceful as the academic declaration from van der Ploeg et al. (2000: 401) that "we reject the notion that rural development can only proceed through the 'expropriation' of agriculture". Furthermore, the interpretation of these experiences suggests that both have worked on sustainability without referring to it that way: the social dimension is pivotal (care of the elderly, women, children, youth, immigrants, etc.); ecological and environmental issues are very present and, as has just been said in regard to agriculture, so is the work on the economic aspects. There is not, therefore, confusion between sustainable

13) PDO (protected designation of origin) is a regional product recognised by the EU. In the case of Monterrei, wine. To attain this labelling, the product must be distinctive and has either regional or local names. The designation is initiated at the regional or national scale and culminates in the EU official recognition. For PDO commodities, production, processing and preparation must take place in a given region.

14) The proposal was sent by the Monterrei PDO to the Galician Ministry for Rural Affairs in 2008 (La Región 02.07.2008) and in July 2009 the extension was officially passed. 21.12.2008)

15) It has been called the "Museum of the Olive Tree", EU-funded INTERREG III (La Región 
development and economic growth, as Mikkelson (2013), Capalbo (2008), Naredo (2007), Sánchez-García (2007), Vázquez-Barquero (2007), Anton and Gonzàlez-Reverté (2005) or other authors warn.

We have already indicated how government policy on rural development has tended to rely on tourism as a future activity in Galicia (Santos 2012, Santos and Paül 2011, Lois and Santos 2004), in line with widespread EU policy recommendations and practices (Böcher 2008, Woods 2005, Ray 2000a). Instead, the studied associations understand that the core elements to rural development are the environment, the socio-cultural dimension and, in terms of economy, the farming sector; tourism, in their "worldview" stance, is merely a complement. In fact, the "tourism" opted for in both experiences is not institutionalised. Fig. 6 show only one officially recognised business as accommodation for rural tourism in both municipalities (in Sarreaus, and it is not $O$ Viso hostel). What we realise from the start is how weak the local tourist economy is in the area. Indeed, our case studies have created two separate hostels which, as they explain, have made an important local impact and have established synergies with the respective communities. Nonetheless, they find themselves on the margins of "official rural tourism" that is recognised administratively - hence their invisibility in Fig. 6. In this sense, it is doubtful that these particular rural localities can be interpreted under the "shift from production to consumption" paradigm proposed by authors such as Scott et al. (2011), Woods (2005), Ray (2000a) or Marsden (1999).

As reported in the previous section, both initiatives have taken partial advantage of available public resources - for example, they have used the $0.52 \%$ for NGOs from income tax, and they have participated, in a direct or an indirect way, in the LEADER and INTERREG programmes. This is worth discussing in terms of the debates between endogenous and neo-endogenous development conceptions (Galdeano-Gómez et al. 2011, High and Nemes 2007, Ray 2006, 2000a). In these experiences their own projects and the rural community's shared visions are more relevant than the arrival of external financial funds from rural development policies. This attitude links with the notions of endogenous development advocated by Vázquez-Barquero $(2006,2007,2009)$ or spontaneous development by Lois and Santos (2004). Furthermore, both case-studies do not follow Ray's (2000a: 4, 2006: 281) acknowledgements that in neo-endogenous development the extra-local factors are "essential", "inevitable" or "crucial". We can claim, in this respect, that "We [...] focus on rural development practices, rather than rural development policies as is currently the case in most sociological analysis. Without wanting to detract from the relevance of the latter, we must be aware that [...] the practical is not triggered by the political" (van der Ploeg et al. 2000: 396).

Indeed, the reception of generous EU funds for institutionalised rural development, type LEADER, is negatively perceived by the participants in both initiatives, which leads us to assess the neo-endogenous approach as quite inconsistent with interviewees' beliefs and values. Moreover, the socio-economic indicators of a net receiving region have remained moribund for more than 20 years of rural development policy, as sharply shown in section 4.1 . This makes the policies and the theoretical underpinnings that sustain these policies rather vacuous. With regard to the implementation of the EU funds, this article reports a specific example of investment that, were it not taken by one of the associations studied in 2007, was to become one more closed-down building constructed or restored with EU programs that scatter the Galician countryside. This reality is also evidenced by the observations of Lois (2004) or Trabada (2007). In this sense, this article leads us to infer that the neo-endogenous development model, as repeatedly formulated, carries no actual development at all on the ground. We agree with Ray (2000a: 110) when he says that "the system, emerging from the logic of neo-endogenous development, may contain a tendency to produce [a] hierarchical 
structure and thereby possibly denying the benefits of the neo-endogenous approach to many rural areas".

From the experiences analysed, we deduce that civil society plays a major role in the activation of rural areas, beyond the usual emphasis placed on the public sector or business activities, just as the endogenous development theory claims (Pike et al. 2007, Vázquez-Barquero 2007). Therefore, our article highlights the need to not confine academic research on rural development to governments and businesses. In fact, initiatives that transcend formal institutions have become particularly relevant in the current climate, given the stifling degree of government paralysis and debt, or the inability of many companies to continue their activities and adapt to a new competitive environment. "The solution to the crisis depends on the use of the potential for development and the actions that come from civil society, inasmuch as development processes that occur as a result of using own resources through projects designed and managed by citizens and local organisations" (Vázquez-Barquero 2009: 13). The two initiatives have been able to withstand more than 20 years, including 5 in crisis, in a regional environment as hard hit as the province of Ourense.

It remains doubtful to what extent the two analysed experiences contribute towards real development. By assessing through the submitted theory and the methodological considerations, the answer must be qualitative. From a strictly quantitative point of view, the critical state of the directly involved parishes ${ }^{16)}$ does not substantially differ from the regional situation. Nevertheless, we must not lose sight of the fact that it has generated economic activity (in the municipality of Sarreaus, $O$ Viso has been recognised as a main activity employer) and that there are young people working in rural areas, although the results are not statistically representative. In any case, and albeit that we refer to non-profit making NGOs or associations, they do help to appoint (and even attract) a particular workforce that they would not otherwise have, or would see emigrate. Nonetheless, we should stress the relevance of qualitative readings following Bessière's (2012) indications in this respect, thus taking into consideration the perceptions on the activation of lost traditions or the development of social services. Indeed, cultural vitality or quality of life are difficult to measure (Bailly 1987), although it has been widely reported that Lodoselo or Arzádegos have improved over the last two decades - something that has been possible thanks to the studied initiatives (not down to action from the municipal councils or the regional government). We refer to development, not growth, which requires us to work with different frameworks and this is in line with recent theoretical proposals such as Jackson (2009), Taibo (2009) and Latouche (2007), who criticise a de facto line of thought in social sciences that is too narrow-mindedly obsessed with economic growth.

Given that governance has been interpreted as a multi-level process (Gkartzios and Scott 2013, Romero and Farinós 2011, High and Nemes 2007, Pike et al. 2007, Woods 2005, Marsden 1999), it is necessary to understand how the two initiatives act in terms of geographical scales:

- Both development centres have "jumped" from their respective hamlets and parishes to the district arena. This is important because they express that a rural development project must have a broad and not narrow scope, i.e. to be able to be easily exported beyond the place of origin.

16) For the parish level, there are only recent demographic databases, but the trend is clearly negative. Arzádegos had 756 inhabitants in 1981; the population has decreased to 344 in 2001 and to 256 in 2011. In the case of the parish of Lodoselo, the figures are also evidently depressing: 477 (1981), 238 (2001) and 194 (2011). 
- An active presence in the district capital small cities (Xinzo, Verín). This is a "stance" that uses these towns to reach the whole district. For example, capture an audience that later heads to Lodoselo or Arzádegos to develop activities. Thus, Xinzo and Verín become "loudspeakers" for the small rural parishes, without sacrificing the latter, and placing them in the district in a way that they would hardly be able to do so alone.

- The connection to other levels: in the province of Ourense, in Galicia, in Spain. Membership to COCEDER not only ensures a joint effort, but it is also a lobby to put pressure on a Spanish scale. There are even links with the EU through funded projects and, as we have already discussed, they are very different to the common use of LEADER or INTERREG funds in Galicia.

From these dynamics, we can see cooperation networks on different scales and with different stakeholders, both public (governments, councils, universities, etc.) and private (social work, foundations, etc.), and both horizontal and vertical in the senses given by Böcher (2008). Our inference in this sense is that endogenous rural development should not be strictly understood as encapsulated in the registration of a hamlet or a parish (a specific locality), as several scholars assume when theorising on endogeneity (Galdeano-Gómez et al. 2011, High and Nemes 2007, Ray 2006, 2000a, 2000b), but open and weaving a dense web of complicities, which in any case means losing local control. O Viso or Portas Abertas strictly follow the logic of bottom-up since they set their agenda and then agree on other levels of partnership with other stakeholders for its implementation. Through these partnerships, we do not find a rejection of public actions but a proactive initiative that seeks to work with them, when it is necessary or possible. It is a way of working which contrasts with the widely established "subsidised attitude" in the European rural areas and it was favoured by the generalisation of EU funds (Barthe and Milian 2011: 157-158).

The LEADER programme has been rhetorically presented as pro-governance given that it has been conceived as bottom-up. However, this aspiration is more an alleged political construction than a reality, as shown by Böcher (2008), Furmankiewicz et al. (2010), Furmankiewicz (2011) or Dax et al. (2013) when analysing particular cases across Europe and demonstrating that the top-down direction is determinant. Nevertheless, the experiences reported here are truly bottom-up and, critically, they only take partial advantage of LEADER and other EU schemes. As expressed by Dax et al. (2013: 9), "it is necessary [...] to counter-balance this tendency [towards bureaucratic, top-down and non-innovative rural development projects across the EU] and to make efforts to re-establish the preconditions for local community action".

\section{Conclusion}

Despite the pessimism to be found in Galician rural areas, particularly gloomy in the province of Ourense regional context, this article suggests that there are hopes for the future. The two studied initiatives confront resignation and despair detected by Lois (2004) or Trabada (2007) in their overall approaches for the whole of the Galician countryside. Similar case-studies should be examined with the same methodology and theoretical framework proposed here in order to test if there are more hopes beyond the two apparently exceptional case-studies analysed. Be that as it may, this paper has shown that at least two rural communities have a very clear idea of what vision - what future - they wish for, following Scott et al.'s (2011) appeal to research into local communities' aspirations.

17) This famous "Mr Average" caricature by Philo (1992) has been enormously discussed in rural geography and indeed has been seminal for further research (the so-called "neglected rural geographies"). For a recent (re)consideration, see Halfacree (2007). 
In British rural geography, it has been very popular to consider the "Mr Average" veneer (Philo 1992: 200) $)^{17)}$, by which rural studies are usually based on statistical averages and thus minimising the nuances and the diversity (Halfacree 2007). Perhaps for this reason, the Galician rural geography has not been able to perceive and understand realities that are able to escape the prevailing socio-economic lethargy being experienced by the Galician countryside. As stated by a participant in one of the experiences, it is necessary to "maintain the capacity to dream when this ability is being lost or it has already been lost in countryside. There lies a huge crisis of utopia".

\section{Acknowledgements}

The author wishes to acknowledge gratefully Xiana Rodil, Dr Juan Manuel Trillo and Daniel del Río, for critically reading the paper. I would also like to thank Dr Sabela Labraña and Dr Miguel Pazos, who kindly reviewed an early draft of this document, Paul Mardlin for improving my English style through successive editions, and the helpful comments and criticisms made by Prof loan lanoş.

\section{References}

ALDREY, J., A. (2006), A poboación galega, 1900-2005. Cambio demográfico e I mplicacións territoriais, Vigo, Ir Indo.

ANTON, S., GONZÀLEZ-REVERTÉ, F., coords. (2005), Planificación territorial del turismo, Barcelona, Universitat Oberta de Catalunya.

BAILLY, A. (1987), Les indicateurs sociaux: des mesures objectives des sciences dures aux évaluations subjectives des sciences molles, Schweizerische Gesellschaft für Volkswirtschaft und Statistik, 123, pp. 341-351.

BANKS, J., MARSDEN, T. (2000), Integrating Agri-Environment Policy, Farming Systems and Rural Development: Tir Cymen in Wales, Sociologia Ruralis, 40, 4, pp. 466-480.

BARTHE, L., MILIAN, J. (2011), Les espaces de la faible densité - état des lieux et problématiques, in: E. Berthier, dir. Territoires 2040. Des systèmes spatiaux en prospective, Datar/La Documentation Française, Paris, pp. 141-183.

BERICAT, E. (1998), La integración de los métodos cuantitativo y cualitativo en la investigación social. Significado y medida, Barcelona, Ariel.

BESSIĖRE, J. (2012), Transformation, recomposition des espaces ruraux et émergence de nouvelles demandes sociales, in J. Bessière, coord. Innovation et patrimoine alimentaire en espace rural, Quæ, Versailles, pp. 21-34.

BÖCHER, M. (2008), Regional Governance and Rural Development in Germany: the Implementation of LEADER+, Sociologia Ruralis, 48, 4, pp. 372-388.

BRINKMAN, R. (1995), Economic Growth versus Economic Development: Toward a Conceptual Clarification, Journal of Economic Issues, XXIX-4, pp. 1171-1188.

CAPALBO, L., comp. (2008), El resignificado del desarrollo, Buenos Aires, Centro de Integración - Comunicación, Cultura y Sociedad.

DAVOUDI, S., FARINÓS, J., PAÜL, V., VRIES, A. de (2009), El desarrollo y la planificación territoriales: entre la perspectiva ambiental, la cohesión social y el crecimiento económico, in: J. M. Feria, A. García-García, and J. F. Ojeda, eds. Territorios, Sociedades y Políticas, Sevilla, Universidad Pablo de Olavide/Asociación de Geógrafos Españoles, pp. 199-238.

DAX, T., STRAHL, W., KIRWAN, J., MAYE, D. (2013), The Leader programme 20072013: Enabling or disabling social innovation and neo-endogenous development? Insights from Austria and Ireland, European Urban and Regional Studies, forthcoming.

DOVAL, A. (2002), La implantación territorial de grupos de acción local y de fundaciones para el desarrollo de las comarcas de Galicia, Xeográfica, 2, pp. 135-154. 
EVANS, N., MORRIS, C., WINTER, M. (2002), Conceptualizing agriculture: a critique of post-productivism as the new orthodoxy, Progress in Human Geography, 26, 3, pp. 313-332.

EYLES, J., SMITH, D. (1988), eds. Qualitative Methods in Human Geography, Cambridge, Polity Press.

FARINÓS, J. (2008), Gobernanza territorial para el desarrollo sostenible: estado de la cuestión y agenda, Boletín de la Asociación de Geógrafos Españoles, 46, pp. 11-32.

FURMANKIEWICZ, M. (2011), Leader+ Territorial Governance in Poland: Successes and Failures as Rational Choice Effect, Tijdschrift voor economische en sociale geografie, 103, 3, pp. 261-275.

FURMANKIEWICZ, M., THOMPSON, N., ZIELIŃSKA, M. (2010), Area-based partnerships in rural Poland: The post-accession experience, Journal of Rural Studies, 26, 1, pp. 5262.

GALDEANO-GÓMEZ, E., AZNAR-SÁNCHEZ, J. A., PÉREZ-MESA, J. C. (2011), The Complexity of Theories on Rural Development in Europe: An Analysis of the Paradigmatic Case of Almería (South-east Spain), Sociologia Ruralis, 51, 1, pp. 54-78.

GARCÍA-RODRÍGUEZ, J.-L., FEBLES, M. F., ZAPATA, V. M. (2005), La iniciativa comunitaria LEADER en España, Boletín de la Asociación de Geógrafos Españoles, 39, pp. 361-398.

GAROFOLI, G. (2002), Local development in Europe. Theoretical models and international comparisons, European Urban and Regional Studies, 9, 3, pp. 225-239.

GKARTZIOS, M., SCOTT, M. (2013), Placing Housing in Rural Development: Exogenous, Endogenous and Neo-Endogenous Approaches, Sociologia Ruralis, forthcoming.

GOERLICH, F., J., MAS, M. (2006), La localización de la población española sobre el territorio. Un siglo de cambios: un estudio basado en series homogéneas (1900-2001), Bilbo, Fundación BBVA.

HALFACREE, K. (1997), Contrasting roles for the post-productivist countryside. A postmodern perspective on counterurbanisation, in: P. Cloke, and J. Little, eds. Contested Countryside Cultures. Otherness, Marginalisation and Rurality, London, Routledge, pp. 67-90.

HALFACREE, K. (2007), Still surprises in store. Revisiting the ordinary in rural geography, Documents d'Anàlisi Geogràfica, 50, pp. 87-103.

HASLAM MCKENZIE, F. (2013), Delivering Enduring Benefits from a Gas Development: Governance and Planning Challenges in Remote Western Australia, Australian Geographer, 44, 3, pp. 341-358.

HAY, I., ed. (2005), Qualitative Research Methods in Human Geography, Melbourne, Oxford University Press.

HIGH, C., NEMES, G. (2007), Social Learning in LEADER: Exogenous, Endogenous and Hybrid Evaluation in Rural Development, Sociologia Ruralis, 47, 2, pp. 103-119.

ILBERY, B., BOWLER, I. (1998), From Agricultural Productivism to Post-Productivism, in: B. Ilbery, ed. The Geography of Rural Change, London, Longman, pp. 57-84.

JACKSON, T. (2009), Prosperity without Growth: Economics for a Finite Planet, London/New York, Earthscan.

LATOUCHE, S. (2007), Petit traité de la décroissance sereine, Paris, Mille et Une Nuits.

LOIS, R., C. (2004), Estrutura territorial de Galicia, in: R. Rodríguez-González, dir. Os concellos galegos para o século XXI. Análise dunha reestruturación do territorio e do goberno local. Santiago de Compostela, IDEGA/FEGAMP, I, pp. 101-160.

LOIS, R., C., SANTOS, X. M. (2004), Planificación y espontaneidad en el desarrollo rural, in: R. Rodríguez-González, and E. Pérez-Correa, coords. Espacios y desarrollos rurales. Una visión múltiple desde Europa y Latinoamérica, Gijón, Trea, pp. 131-156.

LÓPEZ-GONZÁLEZ, A. (2004), A previsión demográfica: o futuro demográfico dos concellos galegos, in: R. Rodríguez-González, R., dir. Os concellos galegos para o século XXI. 
Análise dunha reestruturación do territorio e do goberno local. Santiago de Compostela, IDEGA/FEGAMP, I, pp. 161-202.

MAJORAL, R. (1997), Socioestructuras agrarias en España. Un análisis regional, in: V. Bretón, J. J. Mateu, and F. García-Pascual, coords. La agricultura familiar en España. Estrategias adaptativas y políticas agropecuarias, Lleida, Universitat de Lleida, pp. 45-82.

MARKANTONI, M., KOSTER, S., STRIJKER, D., WOOLVIN, M. (2012), Contributing to a vibrant countryside? The impact of side activities on rural development, Tijdschrift voor economische en sociale geografie, 104, 3, pp. 292-307.

MARSDEN, T. (1999), Rural Futures: The Consumption Countryside and its Regulation, Sociologia Ruralis, 39, 4, pp. 501-526.

MCDONAGH, J. (2013), Rural geography I: Changing expectations and contradictions in the rural, Progress in Human Geography, forthcoming.

MIKKELSON, G. M. (2013), Growth Is the Problem; Equality Is the Solution, Sustainability, 5 , pp. 432-439.

MOLINERO, F., MAJORAL, R., GARCÍA BARTOLOMÉ, J. M., GARCÍA FERNÁNDEZ, G., coords. (2004): Atlas de la España Rural, Madrid, Ministerio de Agricultura, Pesca y Alimentación.

NAREDO, J. M. (2007), Crecimiento insostenible, desarrollo sostenible, in: J. Romero, coord. Geografía humana. Procesos, riesgos e incertidumbres en un mundo globalizado, Barcelona, Ariel, pp. 421-476. Condado.

OJEDA, J., F. (2002), La viña, paisaje ético, Bollullos Par del Condado, Vinícola del 51-57.

OJEDA, J., F. (2003), Desarrollo y Patrimonio Paisajístico, Patrimonio Histórico, 42, pp.

OJEDA, J., F. (2004), El paisaje -como patrimonio-factor de desarrollo de las áreas de montaña, Boletín de la Asociación de Geógrafos Españoles, 38, pp. 273-278.

PHILO, C. (1992), Neglected Rural Geographies: a Review, Journal of Rural Studies, 8 , 2, pp. 193-207.

PIKE, A., RODRÍGUEZ-POSE, A., TOMANEY, J. (2007), What Kind of Local and Regional Development and for Whom?, Regional Studies, 41, 9, pp. 1253-1269.

PLAZA, J., I. (2005), Desarrollo y diversificación en las zonas rurales de España: el programa PRODER, Boletín de la Asociación de Geógrafos Españoles, 39, pp. 399-422.

PLAZA, J., I. (2006), Territorio, geografía rural y políticas públicas. Desarrollo y sustentabilidad en las áreas rurales, Boletín de la Asociación de Geógrafos Españoles, 41, pp. 69-95.

PLOEG, van der J., D. et al. (2000), Rural Development: From Practices and Policies towards Theory, Sociologia Ruralis, 40, 4, pp. 391-408.

RAY, C. (2000a), Culture Economies: a perspective on local rural development in Europe, Newcastle upon Tyne, Centre for Rural Economy.

RAY, C. (2000b), Endogenous socio-economic development in the European Union: issues of evaluation. Journal of Rural Studies, 16, 4, pp. 447-458.

RAY, C. (2006), Neo-endogenous rural development in the EU, in: P. Cloke, T. Marsden, and P. Mooney, eds. Handbook of Rural Studies, London/Thousand Oaks/New Delhi, SAGE, pp. 278-291.

RODRÍGUEZ-GONZÁLEZ, R. (1999), De aldeas a cidades: urbanismo e xeografía das vilas galegas, Vigo, Ir Indo.

RODRÍGUEZ-POSE, A. (2013), Do Institutions Matter for Regional Development?, Regional Studies, 47, 7, pp. 1034-1047.

ROMERO, J., FARINÓS, J. (2011), Redescubriendo la gobernanza más allá del buen gobierno. Democracia como base, desarrollo territorial como resultado, Boletín de la Asociación de Geógrafos Españoles, 56, pp. 295-319. 
RUIZ-OLABUÉNAGA, J. I. (2003), Metodología de la investigación cualitativa, Bilbo, Universidad de Deusto.

SÁNCHEZ-GARCÍA, J. (2007), Caracterización instrumental del concepto de desarrollo local, in: J.-L. García-Rodríguez, and J.Á. Rodríguez-Martín, eds. Teoría y práctica del desarrollo local en Canarias, Islas Canarias, Federación Canaria de Desarrollo Rural, pp. 4967.

SANTOS, X., M. (2012), O turismo en Galicia, in: M.J. Piñeira, and X.M. Santos, coords. Xeografía de Galicia, Xerais, Vigo, pp. 407-428.

SANTOS, X., M., PAÜL, V. (2011), Construíndo o turismo fluvial e de interior na Galiza, in: R. C. Lois, and V. Paül, eds. Turismo fluvial e da natureza. Un elemento de revitalización dos espazos rurais e do interior, A Coruña, Instituto Galego de Estudos Europeos e Autonómicos, pp. 17-34.

SCOTT, A., J., SHORTEN, J., OWEN, R., OWEN, I. (2011), What kind of countryside do the public want: community visions from Wales UK?, GeoJournal, 76, pp. 417-436.

STOKER, G. (1998), Governance as theory: five propositions, International Journal of Social Sciences, 50, 1, pp. 17-28.

TAIBO, C. (2009), En defensa del decrecimiento, Madrid, Catarata.

TAYLOR, S. J., BOGDAN, R. (1984), Introduction to Qualitative Research Methods: the Search for Meanings, New York, John Wiley \& Sons.

TONTS, M., HASLAM MCKENZIE, F. (2005), Neoliberalism and Changing Regional Policy in Australia, International Planning Studies, 10, 3-4, pp. 183-200.

TORRES, M. P. de, LOIS, R. C., PÉREZ-ALBERTI, A. (1993), A montaña galega: o home e o medio, Santiago de Compostela, Universidade de Santiago de Compostela.

TRABADA, E., dir. (2007), Estudo sociolóxico sobre o territorio rural de Galicia, Santiago de Compostela, FOESSA/Cáritas.

VALENTINE, G. (1997), Tell me about...: using interviews as a research methodology, in: R. Flowerdew, and D. Martin, eds. Methods in Human Geography, Harlow, Prentice Hall, pp. 110-126.

VÁZQUEZ-BARQUERO, A. (2006), Endogenous Development. Networking, Innovation, Institutions and Cities, London, Routledge.

VÁZQUEZ-BARQUERO, A. (2007), Desarrollo endógeno. Teorías y políticas de desarrollo territorial, Investigaciones Regionales, 11, pp. 183-210.

VÁZQUEZ-BARQUERO, A. (2009), Una salida territorial a la crisis. Lecciones de la experiencia latinoamericana, Eure, 35, 105, pp. 5-22.

WILSON, G. A. (2007), Multifunctional Agriculture. A Transition Theory Perspective, Wallingford/Cambridge, CABI.

WOODS, M. (2005), Rural Geography. Processes, Responses and Experiences in Rural Restructuring. London/Thousand Oaks/New Delhi/Singapore, SAGE.

WORLD COMMISSION ON ENVIRONMENT AND DEVELOPMENT (1987), Our Common Future, Oxford, Oxford University Press.

Initial submission: 10.05 .2013

Revised submission: 31.10 .2013

Final acceptance: 29.11.2013

Correspondence: Departamento de Xeografía, Facultade de Xeografía e Historia, Praza da Universidade, 1, 15782 Santiago de Compostela, Galicia, Spain.

E-mail: v.paul.carril@gmail.com 